\title{
Common Eider (Somateria mollissima v-nigrum) Nest Cover and Depredation on Central Alaskan Beaufort Sea Barrier Islands
}

\author{
LYNN E. NOEL, ${ }^{1}$ STEPHEN R. JOHNSON,${ }^{2}$ GILLIAN M. O'DOHERTY ${ }^{3}$ and MATTHEW K. BUTCHER ${ }^{4}$
}

(Received 8 December 2003; accepted in revised form 2 September 2004)

\begin{abstract}
Female common eiders (Somateria mollissima v-nigrum) generally select nest sites in areas with driftwood cover. Previous studies of common eiders have shown a positive relationship between nest success and driftwood cover. Our observations led us to hypothesize that cover does not enhance nest success when mammalian predators are present. To evaluate nest cover selection in common eiders, we examined five years of nesting data to determine the interactions between the probability of nest activity and the amount of driftwood cover in the presence of avian versus mammalian predators. Most common eider nests were surrounded by low (40\%) or moderate (38\%) driftwood cover. Nest failure rates were high (32\%-95\%), and arctic foxes (Alopex lagopus), alone or with polar bears (Ursus maritimus), appeared to be more destructive than glaucous gulls (Larus hyperboreus) to eider nests. Logistic regression was used to model common eider nest activity associated with driftwood cover and predators. When glaucous gulls were the only predators, more driftwood cover consistently increased the probability of nest activity. But when foxes were present, nest activity consistently decreased with increasing cover. Our models support our observations that nest cover was beneficial to eiders when glaucous gulls alone were predators. Driftwood cover may be most important for the thermal and structural protection it offers, rather than for the camouflage it provides. The energetic benefit provided by driftwood windbreaks coupled with the common eider's behavioral response of decreased nest attendance, or increased exposure to avian depredation of nests as energy reserves are depleted during incubation, provides an explanatory mechanism for our model results.
\end{abstract}

Key words: arctic fox, Alopex lagopus, driftwood habitat, egg depredation, glaucous gull, Larus hyperboreus, polar bear, Ursus maritimus

RÉSUMÉ. L'eider à duvet femelle (Somateria mollissima v-nigrum) choisit en général son site de nidification dans des zones ayant un couvert de bois flotté. Des études précédentes sur les eiders à duvet ont révélé qu'il existe une relation positive entre le succès de la couvée et le couvert de bois flotté. Nos observations nous ont amenés à émettre l'hypothèse que le couvert n'augmente pas le succès de la couvée en présence de prédateurs mammifères. Afin d'évaluer le choix de couvert du nid chez l'eider à duvet, nous avons examiné des données de nidification obtenues sur cinq années, en vue de dégager les interactions entre la probabilité d'activité au nid et la quantité de couvert de bois flotté en présence de prédateurs aviens par opposition aux prédateurs mammifères. La plupart des nids de l'eider à duvet étaient entourés par un faible couvert de bois flotté (40\%) ou un couvert modéré (38 \%). Les taux d'insuccès étaient élevés (32 à $95 \%$ ) et le renard arctique (Alopex lagopus), seul ou avec l'ours polaire (Ursus maritimus), semblait plus destructeur pour les nids de l'eider que le goéland bourgmestre (Larus hyperboreus). On a utilisé la régression logistique pour simuler l'activité au nid de l'eider à duvet associée au couvert de bois flotté et aux prédateurs. Quand le goéland bourgmestre était le seul prédateur, une plus grande quantité de bois flotté augmentait toujours la probabilité d'activité au nid. En revanche, en présence du renard, l'activité au nid diminuait toujours avec une augmentation du couvert. Nos modèles viennent appuyer nos observations à l'effet que le couvert du nid représentait un avantage pour l'eider quand le goéland bourgmestre était le seul prédateur. Le couvert de bois flotté pourrait bien être d'une importance capitale en raison de la protection thermique et structurale qu'il offre, plutôt que pour ses capacités de camouflage. L'avantage énergétique qu' offrent les brise-vent de bois flotté joint à la réaction comportementale de l'eider à duvet - qui se manifeste par une plus grande présence au nid, ou une plus grande exposition à une déprédation avienne du nid à mesure que s'épuisent les réserves d'énergie durant l'incubation -, ces deux éléments donc fournissent un mécanisme pouvant expliquer les résultats de notre modèle.

Mots clés: renard arctique, Alopex lagopus, habitat de bois flotté, déprédation des œufs, goéland bourgmestre, Larus hyperboreus, ours polaire, Ursus maritimus

Traduit pour la revue Arctic par Nésida Loyer.

\footnotetext{
${ }^{1}$ Corresponding author: LGL Alaska Research Associates, Inc., 1101 East 76th Avenue, Suite B, Anchorage, Alaska 99518, U.S.A.; present address: ENTRIX, Inc., 1600 A Street, Suite 304, Anchorage, Alaska 99501, U.S.A.; lnoel@entrix.com

${ }^{2}$ LGL Limited, environmental research associates, 9768 Second Street, Sidney, British Columbia V8L 3Y8, Canada; srj@1gl.com

${ }^{3}$ LGL Alaska Research Associates, Inc., 1101 East 76th Avenue, Suite B, Anchorage, Alaska 99518, U.S.A.; godoherty@ hotmail.com

${ }^{4}$ ENTRIX, Inc., 2701 First Avenue, Suite 500, Seattle, Washington 98121, U.S.A.; mbutcher@entrix.com

(C) The Arctic Institute of North America
} 


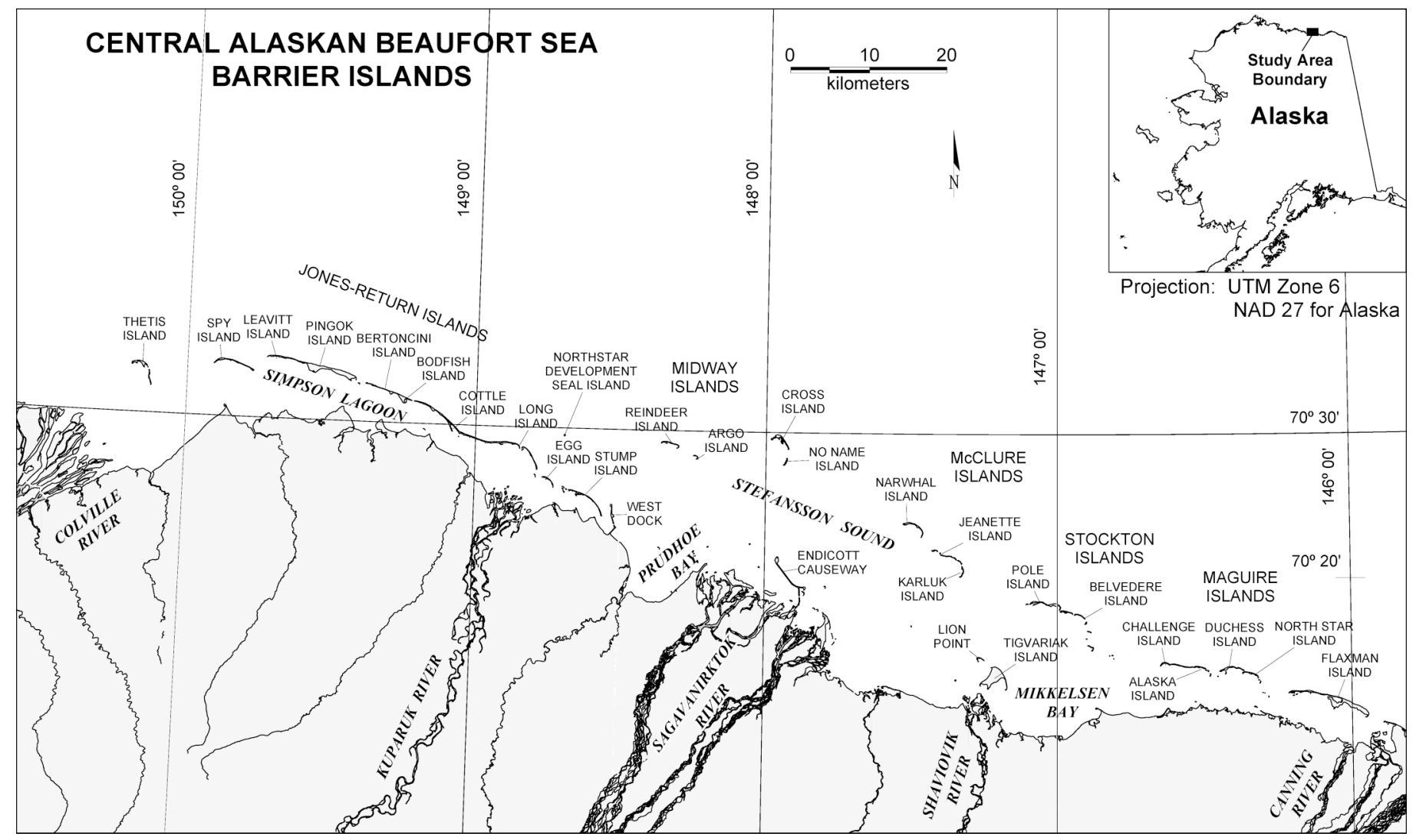

FIG. 1. Barrier islands from Thetis Island to Flaxman Island in the central Alaskan Beaufort Sea.

\section{INTRODUCTION}

Sea duck populations, including the Pacific race of the common eider Somateria mollissima v-nigrum, appear to be in decline on a global level (USFWS, 1999; Suydam et al., 2000). Specific concern has been expressed because of the reported 53\% decline from 1976 to 1994 in the number of common eiders migrating past Point Barrow in the spring (Suydam et al., 2000). Although over $70000 \mathrm{com}-$ mon eiders migrate through the Beaufort Sea each spring (Suydam et al., 2000), only about 2700 common eiders remain to nest along the Beaufort Sea coast of Alaska (Dau and Hodges, 2003). Of these, about $40 \%$ occur between the Colville River and the Canning River (Fig. 1; Dau and Hodges, 2003), with a total average of about 670 nests/ year from 1982 to 2002 (Table 1).

Most common eiders nest in loose aggregations or colonies on sand-and-gravel barrier islands off the Beaufort Sea coast (Johnson, 2000). The most productive aggregations often nest in driftwood on relatively high-elevation islands in the flood plumes of large rivers (Table 1; Johnson, 2000). Common eiders probably select these islands because spring overflow covers the nearshore sea ice in late May through early June. By surrounding these islands within the river flood plumes earlier in spring than neighboring islands, the overflow effectively isolates them from foxes (Johnson, 2000). Polar bears, which can swim or walk over the ice, may access the islands throughout the nesting period. Humans generally require open water to access nest islands by boat for subsistence use. Arctic foxes may access islands over the sea ice either before the spring overflow or during late June to early July, when winds may aggregate ice along the northern edges of the barrier islands. Accessing the islands prior to nest initiation would provide little benefit to foxes, as eiders avoid nesting on islands with foxes and may also avoid locations where foxes destroyed their nests in previous years (Bustnes and Erikstad, 1993). Nests are initiated during mid to late June (Johnson and Herter, 1989), and female common eiders generally select nest sites in areas with driftwood or vegetation to provide concealment or other benefits for the hen and nest (Fig. 2), although nests are sometimes located on bare sand or gravel without driftwood or vegetative cover.

Previous studies of common eiders indicated a positive relationship between nest success and driftwood cover (Johnson et al., 1987). Depredation of common eider eggs and ducklings by arctic foxes (Alopex lagopus) and glaucous gulls (Larus hyperboreus) can be substantial in some years (Larson, 1960) and is known to have been a major factor in eider population declines in southern Sweden (Pehrsson, 1973). Our observations over the years have led us to hypothesize that while cover enhances nest success when glaucous gulls are the only predators, this benefit is lost once mammalian predators gain access to an island. We have observed tracks of mammalian predators that had 


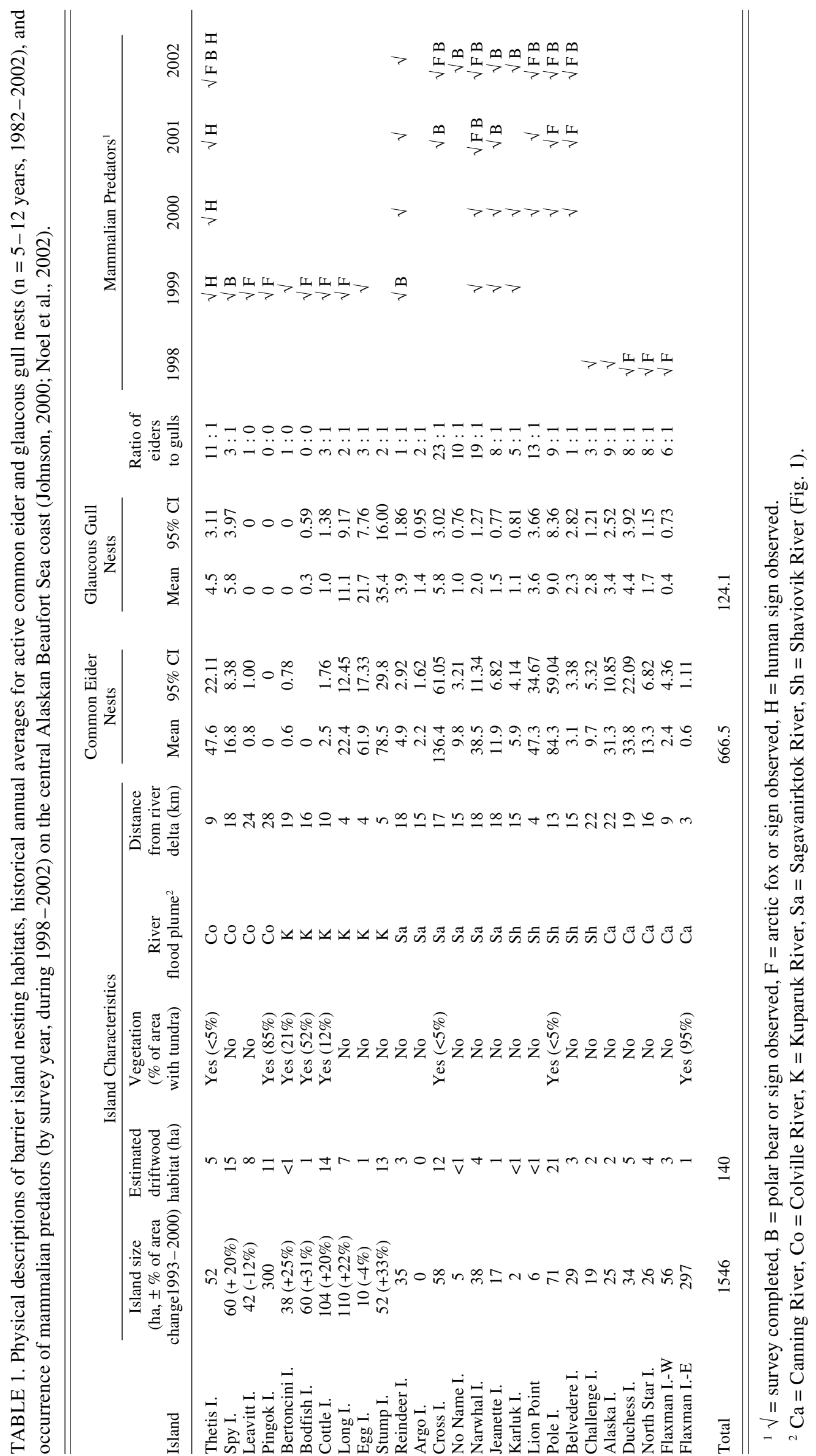



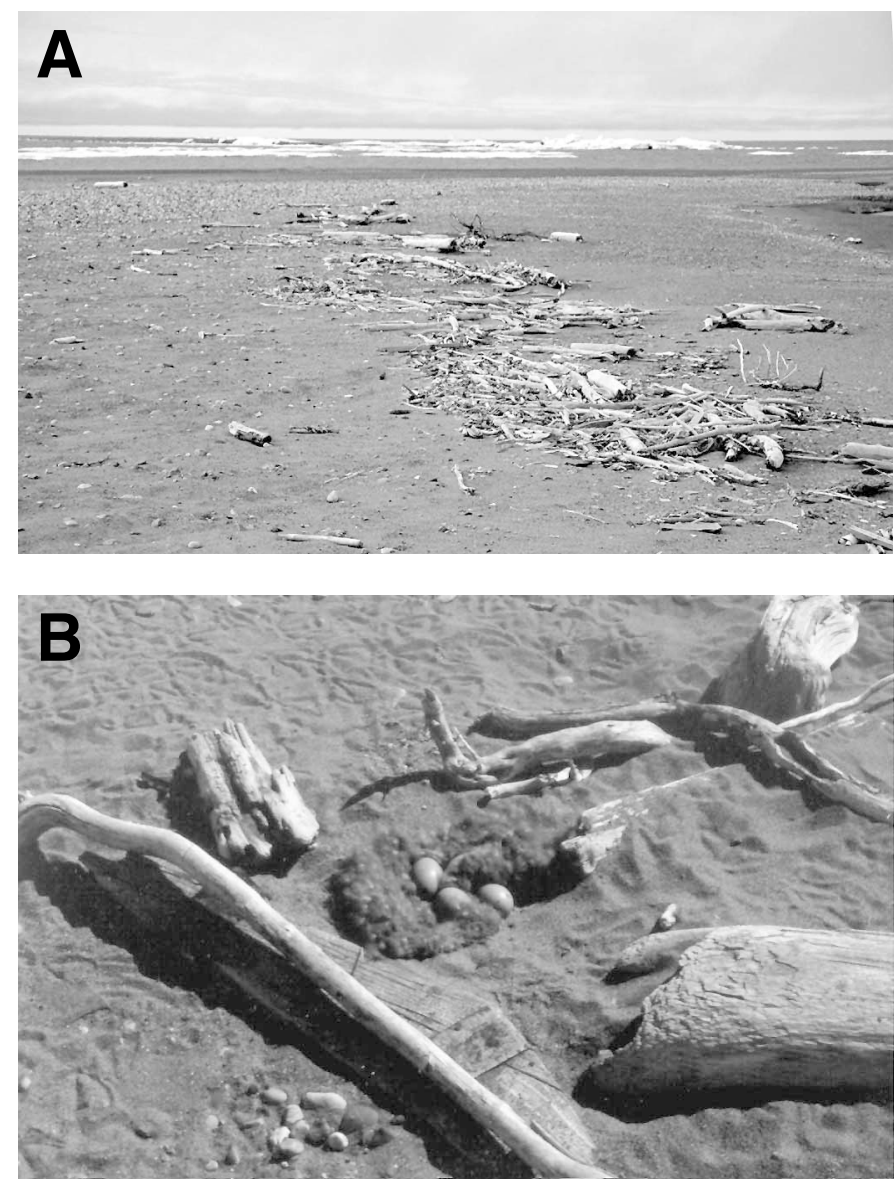

FIG. 2. Examples of island nesting habitats, central Alaskan Beaufort Sea. A) Driftwood accumulation on the eastern end of Narwhal Island. B) Mediumdensity driftwood surrounding an active common eider nest with four live eggs, fresh down, and fresh tracks.

followed lines of driftwood deposits in what appeared to be a systematic search for common eider nests. To assess this hypothesis, we examined five years of nesting data collected on islands in the central Alaskan Beaufort Sea for interactions between nest activity (active or failed) and driftwood cover density in the presence of different predators to evaluate factors important for nest cover selection in common eiders.

\section{METHODS}

Between 1998 and 2002, we searched the entire surface area of 5-13 barrier islands in the Beaufort Sea once a year, in mid July, to document the number of nests of common eiders and glaucous gulls present during mid to late incubation (Table 1; Noel et al., 2002). During surveys, we recorded the number of active and failed nests, as well as evidence of predators. Access to the islands was by helicopter or by boat. Nest searches were conducted on foot by two to five observers spaced across the width of the island. For each observation, we recorded the species, nest status (active or failed), driftwood density, and presence of vegetation near the nest. We tried to avoid flushing incubating hens from nests. If a hen did flush, we recorded the number of eggs and then covered the eggs with down and twigs to minimize their exposure to predators.

Driftwood density was classified into four categories by visually estimating the percentage of ground covered by driftwood within a $0.5 \mathrm{~m}$ radius of the nest bowl. Density categories included none ( $0 \%)$, low (1\% to $33 \%$ ), medium ( $34 \%$ to $66 \%$ ), and high (67\% to $100 \%$ ) density (Johnson et al., 1987). Nests included a pronounced bowl with eggs, or some associated fresh down and eider tracks, or both (Fig. 2; Johnson et al., 1987; Johnson, 1990, 2000; Noel et al., 2002). Evidence of the previous year's nests had usually been blown or washed from the island surface during late summer through winter. Nests were classified as active if they contained one or more live eggs, or were occupied by a laying/incubating female, or contained thickened eggshell membranes (evidence of successful hatching). Nests were considered failed when eggshell fragments in the nest bowl or vicinity indicated that a bird or mammal had eaten or dislodged the eggs, or when nests with fresh down contained no eggs.

Predator occurrence by island for each year was determined from signs near the disturbed nests such as fresh tracks or scat, from the characteristics of remaining egg fragments, or by direct observation of predators on the island (Table 1). Depredated eggs with rounded openings were generally considered a sign of avian predators, as were nests with fresh down and no eggs or eggshell fragments. When there were sightings of mammalian predators, or fresh signs such as fox or bear tracks, scat, or hair, nest failure was considered to be due to mammalian predators. We included observations of human signs as evidence of predation on islands where humans might have used eggs as a subsistence resource, or where disturbance due to human presence might facilitate nest depredation by avian predators (Bolduc and Guillemette, 2003).

Logistic regression was used to model common eider nest activity associated with driftwood cover and different predators, for a total of 2022 common eider nest records (Manly et al., 1993). Two regression models were used to evaluate nest activity associated with densities of driftwood cover in the presence of avian and mammalian predators. Driftwood density categories and the presence of predator species were the independent variables regressed on nest activity (active or failed) in the following model:

Nest Activity $=\frac{\exp \left(\beta_{0}+\beta_{\mathrm{i}} \times \text { Drift }_{\mathrm{i}}+\beta_{\mathrm{j}} \times \text { Predator }_{\mathrm{j}}+\beta_{\mathrm{ij}} \times \text { Drift }_{\mathrm{i}}, \text { Predator }_{\mathrm{j}}\right)}{1+\exp \left(\beta_{0}+\beta_{\mathrm{i}} \times \text { Drift }_{\mathrm{i}}+\beta_{\mathrm{j}} \times \text { Predator }_{\mathrm{j}}+\beta_{\mathrm{ij}} \times \text { Drift }_{\mathrm{i}}, \text { Predator }_{\mathrm{j}}\right)}$

where Nest Activity $=$ whether a nest was active (1) or failed (0), as defined above; $\beta_{0}=$ model intercept; Drift $_{i}=$ driftwood cover density (none, low, medium, high); $\beta_{\mathrm{i}}=$ model coefficients associated with cover; Predator $_{j}=$ presence of predators (glaucous gull, arctic fox, polar bear, human); and $\beta_{\mathrm{j}}=$ model coefficients associated with predator species. 
The subscripted independent variables denote the dummy-effect variables associated with the different densities of driftwood cover and predator type and their interactions. This notation was used for brevity in description of the model. These variables take a value of 1 when a driftwood cover density or predator type was present, and 0 otherwise. A maximum likelihood loss function was used to fit the regression model to the data. SYSTAT 10 was used to conduct the analyses (SPSS, 2000).

The effects of different driftwood cover densities, predator types, and their interactions are represented in the results by their coefficients in each regression model. In the first model, the dummy variable ONLYGULL took a value of 1 for islands containing only glaucous gulls as potential predators, and 0 otherwise (i.e., when any mammalian predator also occurred). This allowed us to measure the effect of cover when only avian predators were present. In a second model, dummy variables were included for each mammalian predator type. Odds Ratios associated with driftwood cover densities, predator types, and their interactions are also reported. The Odds Ratio is the amount by which the proportion of probabilities, $p$ (active) $: p$ (failed), that a nest will be active or failed changes with the effect of the explanatory variable. For example, if the Odds Ratio $=1.6$ for medium-density driftwood cover, the proportion of probabilities will increase, on average, by $60 \%$ in the presence of more driftwood. If an explanatory variable is significant at $\alpha=$ 0.05 in the logistic model, the $95 \%$ confidence interval on its Odds Ratio will not contain 1.

All islands had glaucous gulls as potential predators, and one or more mammalian predator types also occurred on many of the islands (Table 1). Because of this "mixture of predators," the effect of any given predator, independent of others, could not be determined. Likewise, because of the limited numbers of observations and the inherently uncontrolled nature of these combinations of predator types, their interactions were also not quantified.

\section{RESULTS}

Eider hens remained sitting on $66 \%$ of active nests, $32 \%$ of active nests contained $1-8$ live eggs, and $2 \%$ contained thickened eggshell membranes indicating a successful hatch. Most failed nests (97\%) contained no dead eggs or shell fragments. Only $4 \%$ of common eider nests were found with no associated driftwood cover (Table 2). Most common eider nests observed were in low $(40 \%)$ or medium (38\%) driftwood cover (Table 2). Arctic foxes, alone or with polar bears, appeared to be more destructive to eider nests than glaucous gulls (Table 2). When no mammalian predators were present on an island, the numbers of attempted nests (active nests + failed nests) of common eiders and glaucous gulls were positively correlated $(n=23$, $\mathrm{r}=0.48, p=0.019)$, indicating that both species were attracted to the same islands. On islands with no mammalian predators, the proportion of common eider nests that were active was negatively correlated to the number of active glaucous gull nests $(\mathrm{n}=23, \mathrm{r}=-0.032, p=0.153)$. Although this correlation is not statistically significant, it indicates that nesting with increasing numbers of glaucous gulls may be detrimental to common eiders.

The ONLYGULL model allowed measurement of the effect of cover in the presence of avian predators only (Table 3). Overall this model correctly predicted $47 \%$ of active nests and $75 \%$ of failed nests observed. For the interaction terms (ONLYGULL vs. different driftwood cover densities), Odds Ratios consistently increased with increasing cover when gulls were the only predators. While their $95 \%$ confidence intervals overlap, the Odds Ratios roughly double with each change from low- to medium-density and medium- to high-density driftwood cover, demonstrating a consistent trend: that more cover increased the probability of nest activity (Fig. 3).

When mammalian predators were included in the regression model, $52 \%$ of active nests and $77 \%$ of failed nests observed were correctly predicted. As noted in the methods, the interaction effects between mammalian predators were not considered. Nest activity changed $(p=0.03)$ with changing cover only where nests were associated with high densities of driftwood cover (Odds Ratio $=2.8$ ) (Table 4). This overall effect probably reflects the dominance of gulls as nest predators.

Arctic foxes were present on more islands than either humans or polar bears, and this larger sample size may explain their significant results (Table 1). The pattern of nest activity in different driftwood cover densities with foxes present was the reverse of the pattern observed with gulls. When foxes were present, nest activity consistently decreased with increasing cover (Fig. 3). As was the case for gulls, the $95 \%$ confidence intervals for these Odds Ratios overlapped; this may reflect our inability to completely separate the effects of different predators on nest activity, or it may be a result of the categorization of cover. Nest activity did not change significantly with driftwood cover density in the presence of polar bears, although the tendency toward higher activity in nests with low cover approached significance $(p=0.06)$. Similarly, nest activity did not change significantly with changing cover amounts in the presence of humans.

\section{DISCUSSION}

The barrier island habitats between the Colville River and the Canning River are dynamic, with high nest depredation rates $(32 \%-95 \%$, Table 2$)$, and in recent years common eider productivity has been extremely low (Flint et al., 2003). Human disturbance on the islands-including nest surveys and intensive eider research - contributes to nest losses (Bolduc and Guillemette, 2003), but the presence of arctic foxes usually results in loss of all nests (95\% failure rate, Table 2 ). 
TABLE 2. Summary of data for driftwood nest cover (within a $0.5 \mathrm{~m}$ radius of common eider nest bowls) and nest fate (in the presence of different predators) used in logistic regression models. Data are based on one mid July visit to Alaskan Beaufort Sea barrier islands each year from 1998 to 2002 .

\begin{tabular}{|c|c|c|c|c|c|c|c|c|}
\hline \multirow[b]{3}{*}{ Predator Presence } & \multirow{2}{*}{\multicolumn{4}{|c|}{ Driftwood Cover }} & \multicolumn{4}{|c|}{ Nest Fate } \\
\hline & & & & & \multicolumn{2}{|c|}{ Active } & \multicolumn{2}{|c|}{ Failed } \\
\hline & None & Low & Medium & High & Number & Percent & Number & Percent \\
\hline Glaucous gull only & 18 & 282 & 297 & 154 & 439 & $58.5 \%$ & 312 & $41.5 \%$ \\
\hline Arctic fox & 9 & 197 & 169 & 85 & 25 & $5.4 \%$ & 435 & $94.6 \%$ \\
\hline Polar bear & 17 & 89 & 97 & 30 & 67 & $28.8 \%$ & 166 & $71.2 \%$ \\
\hline Arctic fox and polar bear & 28 & 193 & 158 & 67 & 43 & $9.6 \%$ & 403 & $90.4 \%$ \\
\hline Human & 3 & 35 & 40 & 17 & 65 & $68.4 \%$ & 30 & $31.6 \%$ \\
\hline Human, arctic fox and polar bear & 0 & 22 & 9 & 6 & 14 & $37.8 \%$ & 23 & $62.2 \%$ \\
\hline Total & 75 & 818 & 770 & 359 & 653 & $32.3 \%$ & 1369 & $67.7 \%$ \\
\hline
\end{tabular}

TABLE 3. Logistic regression output for model $^{1}$ of driftwood cover effect on common eider nest activity when gulls or other birds were the only predators. Significance at $\alpha=0.05$ is shown in bold.

\begin{tabular}{|c|c|c|c|c|c|c|c|}
\hline \multirow[b]{2}{*}{ Parameter } & \multirow[b]{2}{*}{ Estimate } & \multirow[b]{2}{*}{ Standard Error } & \multirow[b]{2}{*}{ t-Ratio } & \multirow[b]{2}{*}{ Probability } & \multirow[b]{2}{*}{ Odds Ratio } & \multicolumn{2}{|c|}{$95 \%$ Bounds } \\
\hline & & & & & & Upper & Lower \\
\hline Constant & -0.941 & 0.295 & -3.192 & 0.001 & - & - & - \\
\hline $1 \%-33 \%$ driftwood cover & -0.844 & 0.319 & -2.643 & 0.008 & 0.430 & 0.804 & 0.230 \\
\hline $34 \%-66 \%$ driftwood cover & -0.621 & 0.319 & -1.948 & 0.051 & 0.537 & 1.004 & 0.288 \\
\hline $67 \%-100 \%$ driftwood cover & -0.507 & 0.344 & -1.474 & 0.141 & 0.602 & 1.182 & 0.307 \\
\hline Gulls & 0.489 & 0.566 & 0.864 & 0.388 & 1.631 & 4.947 & 0.537 \\
\hline Gulls $\times 1 \%-33 \%$ driftwood cover & 1.054 & 0.592 & 1.781 & 0.075 & 2.869 & 9.151 & 0.899 \\
\hline Gulls $\times 34 \%-66 \%$ driftwood cover & 1.561 & 0.591 & 2.639 & 0.008 & 4.761 & 15.174 & 1.494 \\
\hline Gulls $\times 67 \%-100 \%$ driftwood cover & 2.379 & 0.627 & 3.791 & 0.000 & 10.789 & 36.904 & 3.154 \\
\hline
\end{tabular}

${ }^{1}$ Log-likelihood $\chi^{2}=-1050.986, \mathrm{df}=7, p=0.000, \mathrm{R}^{2}=0.174$.

Common eiders and glaucous gulls share barrier-island nesting habitats, often to the detriment of the nesting common eiders ( $41 \%$ failure rate; Table 2$)$. In the data from islands used for this study, average ratios of common eider nests to glaucous gull nests range from 1:1 to 23:1 (Table 1). The positive correlation between numbers of common eider and glaucous gull nest attempts suggests these species are attracted to similar habitats free of mammalian predators. The weak but negative correlation between the proportion of active common eider nests and the number of active glaucous gull nests, however, suggests that this relationship is not entirely beneficial to the eiders. Our models support our observation that selection for driftwood cover is beneficial to common eiders when glaucous gulls are also present.

Interestingly, while eider nests may be cryptic at ground level, they are quite visible from the air, as demonstrated by trial aerial videographic surveys for eider nests on the barrier islands (Fig. 4; C. Dau and R. Anthony, U.S. Fish and Wildlife Service, pers. comm. 2003). It appears unlikely that cover is selected to "hide" the eider nest from an aerial perspective. Trials with nest cover boxes and simple cross frames on Spy Island in the 1980s demonstrated that common eider hens of the Pacific subspecies were reluctant to use overhead cover, but would use the leeward side of simple crossed-board structures (Johnson et al., 1987; Divoky and Suydam, 1995). Nest bowls are usually constructed as

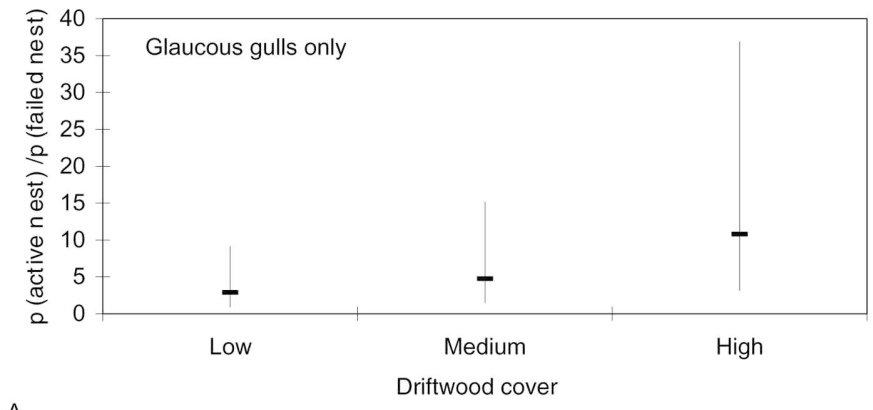

A

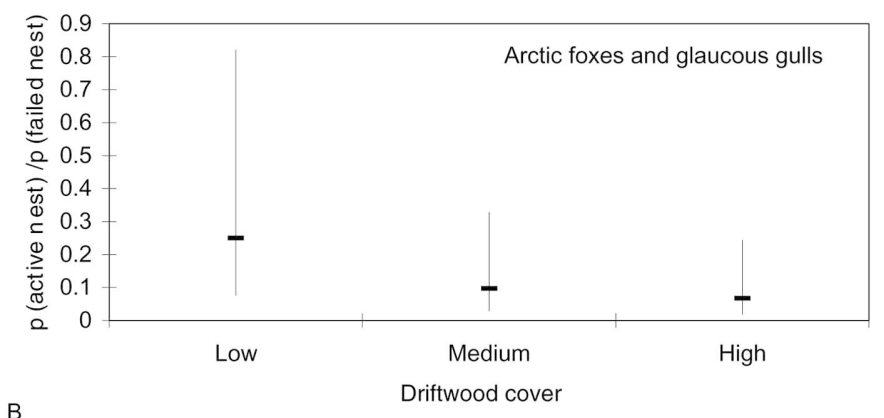

FIG. 3. Trends for Odds Ratios ( $p$ (active) : $p$ (failed)) of common eider nests with glaucous gulls only as predators (A) and with mammalian predators (B).

close as possible to the drift logs (Fig. 4), which provide a windbreak against the often ice-chilled prevailing northeast winds. Driftwood cover around the nest bowl may also 
TABLE 4. Logistic regression output for model $^{1}$ of driftwood cover effect on common eider nest activity when any mammalian predators were present. Significance at $\alpha=0.05$ is shown in bold.

\begin{tabular}{|c|c|c|c|c|c|c|c|}
\hline \multirow[b]{2}{*}{ Parameter } & \multirow[b]{2}{*}{ Estimate } & \multirow[b]{2}{*}{ Standard Error } & \multirow[b]{2}{*}{ t-Ratio } & \multirow[b]{2}{*}{ Probability } & \multirow[b]{2}{*}{ Odds Ratio } & \multicolumn{2}{|c|}{$95 \%$ Bounds } \\
\hline & & & & & & Upper & Lower \\
\hline Constant & 0.067 & 0.429 & 0.156 & 0.876 & - & - & - \\
\hline $1-33 \%$ driftwood cover & -0.492 & 0.444 & -1.107 & 0.268 & 0.612 & 1.461 & 0.256 \\
\hline $34-66 \%$ driftwood cover & 0.283 & 0.444 & 0.638 & 0.523 & 1.328 & 3.172 & 0.556 \\
\hline $67-100 \%$ driftwood cover & 1.015 & 0.464 & 2.184 & 0.029 & 2.758 & 6.855 & 1.110 \\
\hline Arctic fox & -0.427 & 0.570 & -0.749 & 0.454 & 0.653 & 1.994 & 0.214 \\
\hline Polar bear & -1.347 & 0.566 & -2.380 & 0.017 & 0.260 & 0.788 & 0.086 \\
\hline Human & 0.626 & 1.298 & 0.483 & 0.629 & 1.871 & 23.807 & 0.147 \\
\hline Arctic fox $\times 1-33 \%$ driftwood cover & -1.385 & 0.606 & -2.285 & 0.022 & 0.250 & 0.821 & 0.076 \\
\hline Arctic fox $\times 34-66 \%$ driftwood cover & -2.334 & 0.622 & -3.754 & 0.000 & 0.097 & 0.328 & 0.029 \\
\hline Arctic fox $\times 67-100 \%$ driftwood cover & -2.700 & 0.657 & -4.107 & 0.000 & 0.067 & 0.244 & 0.019 \\
\hline Polar bear $\times 1-33 \%$ driftwood cover & 1.145 & 0.601 & 1.907 & 0.057 & 3.144 & 10.205 & 0.969 \\
\hline Polar bear $\times 34-66 \%$ driftwood cover & 0.509 & 0.605 & 0.842 & 0.400 & 1.664 & 5.444 & 0.509 \\
\hline Polar bear $\times 67-100 \%$ driftwood cover & 0.498 & 0.660 & 0.755 & 0.450 & 1.646 & 5.998 & 0.451 \\
\hline Human $\times 1-33 \%$ driftwood cover & 0.145 & 1.334 & 0.109 & 0.913 & 1.157 & 15.810 & 0.085 \\
\hline Human $\times 34-66 \%$ driftwood cover & 0.724 & 1.362 & 0.532 & 0.595 & 2.063 & 29.754 & 0.143 \\
\hline Human $\times 67-100 \%$ driftwood cover & 1.376 & 1.500 & 0.917 & 0.359 & 3.957 & 74.826 & 0.209 \\
\hline
\end{tabular}

${ }^{1}$ Log-likelihood $\chi^{2}=-956.235, \mathrm{df}=15, p=0.000, \mathrm{R}^{2}=0.248$

physically block gulls from accessing the edges of the nest, thus protecting the eggs.

The thermal benefit provided by driftwood cover increases the probability of nest activity by reducing energy expenditure during incubation (Kilpi and Lindström, 1997). Field and laboratory experiments have shown that common eider hens with depleted energy reserves spend more time away from their nests (Bottitta, 1999; Criscuolo et al., 2002), thus increasing nest exposure to avian predators. This behavioral response to depleted energy reserves, coupled with the thermal benefit provided by a driftwood windbreak, provides a mechanism for the positive relationship between common eider nest activity and density of driftwood cover when glaucous gulls are the only nest predators. This relationship was specific for the immediate vicinity of the nest bowl (within a 0.5 m radius), as increased nest survival was not found to be related to the amount of driftwood cover within larger island sections (Johnson et al., 1987).

Driftwood cover does not appear to protect eider nests from mammalian predators; in fact, it may be detrimental to select areas with high driftwood cover when foxes gain access to an island. Fox tracks on these islands usually follow a path from one piece of driftwood to the next, as foxes actively search for eider nests. Polar bear tracks do not usually follow this pattern. Bears tend to walk across the middle of an island, and their tracks are not usually associated with nest sites. We suspect that many of the nests disturbed by polar bears may actually be depredated by glaucous gulls or other avian predators, although we have observed some nests where eggs seemed to have been consumed by polar bears.

In summary, these data confirm the suspected relationship between driftwood density and nest success identified by Johnson et al. (1987). We have further clarified that the probability of nest activity is eight times as great with high
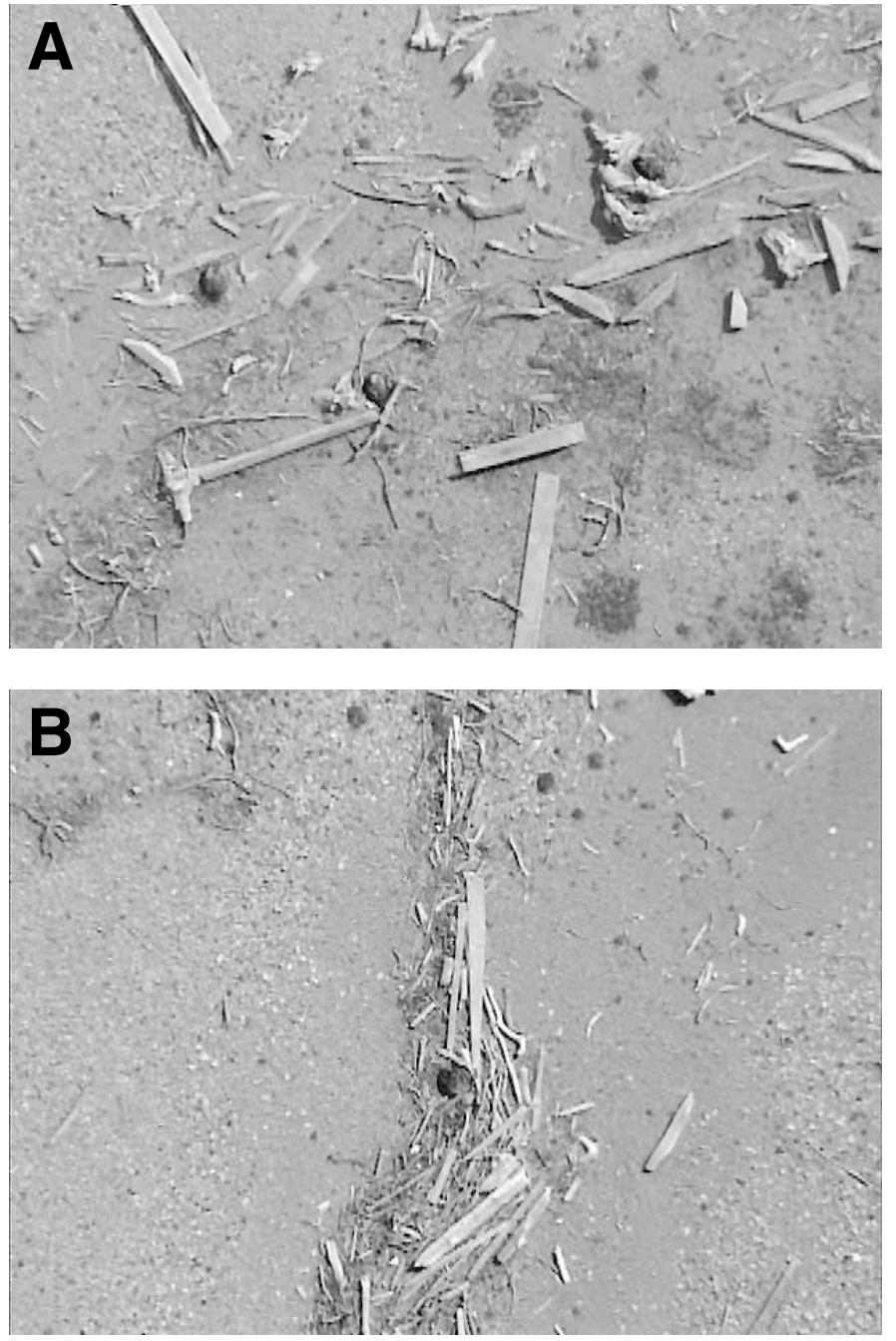

FIG. 4. Aerial view of common eider nests in driftwood accumulations on barrier islands in the central Alaskan Beaufort Sea (provided by R. Anthony, U.S. Geological Survey, Alaska Science Center). A). Three eider nests in medium driftwood cover. B). One eider nest in high driftwood cover. 
driftwood cover as it is with low driftwood cover when avian species are the only predators present. However, cover has little benefit when mammalian predators gain access to an island. Counterintuitively, the protection offered by driftwood may be most important for the thermal and structural protection it offers, rather than for the camouflage it provides. The energetic benefit provided by driftwood windbreaks (Kilpi and Lindström, 1997), coupled with the behavioral response of decreased nest attendance as energy reserves are depleted (Bottitta, 1999; Criscuolo et al., 2002), provides an explanatory mechanism for our model results. Driftwood cover was not found to provide a benefit when mammalian predators accessed nest islands, and we would be unable to quantify this relationship without considering predator involvement.

\section{ACKNOWLEDGEMENTS}

Field programs from 1998 to 2002 and preparation of this manuscript were funded by BP Exploration (Alaska) Inc. (BP), the Point Thomson Unit Owners (BP, ExxonMobil Production Company, Conoco Phillips Alaska, Inc., and others). ENTRIX, Inc. provided support for manuscript development. For assistance with this study we thank W. Streever, D. Trudgen, A. Erickson, and W. Cullor, BP Environmental Studies Group. W. Streever, BP Environmental Studies Group Leader, provided comments that improved this manuscript. C. Baily, BP External Affairs, coordinated with the Nuiqsut Whaling Captains Association to obtain permission for access to Cross Island. R. Anthony of the U.S. Geological Survey, Alaska Science Center, provided video coverage for the barrier islands during 2000-01 and the images in Figure 4. K. Brown, S. Haskell, D. Helmericks, I. Helmericks, S. MacLean, T. Olson, and R. Rodrigues assisted with the nest searches. We thank ERA Aviation and Air Logistics, Inc. for coordinating logistics for helicopter access to the islands during the 1998-2000 field programs. We thank BP's Northstar logistics office for coordinating helicopter access to the islands during the field programs in 2001 02. Lynne Dickson and two anonymous reviewers provided insightful comments, which improved this manuscript.

\section{REFERENCES}

BOLDUC, F., and GUILLEMETTE, M. 2003. Human disturbance and nesting success of common eiders: Interaction between visitors and gulls. Biological Conservation 110:77-83.

BOTTITTA, G.E. 1999. Energy constraints on incubating common eiders in the Canadian Arctic (East Bay, Southampton Island, Nunavut). Arctic 52(4):425-429.

BUSTNES, J.O., and ERIKSTAD, K.E. 1993. Site fidelity in breeding common eider Somateria mollissima females. Ornis Fennica 70:11-16.

CRISCUOLO, F., GABRIELSEN, G.W., GENDNER, J.-P., and LE MAHO, Y. 2002. Body mass regulation during incubation in female common eiders Somateria mollissima. Journal of Avian Biology 33:83-88.
DAU, C.P., and HODGES, J.I. 2003. Aerial population survey of common eiders and other waterbirds in nearshore waters and along barrier islands of the Arctic Coastal Plain of Alaska, 27-30 June 2003. Unpubl. report. Available from U.S. Fish and Wildlife Service, Migratory Bird Management, 1011 East Tudor Road, Anchorage, Alaska 99503. 18 p.

DIVOKY, G.J., and SUYDAM, R. 1995. An artificial nest site for Arctic nesting common eiders. Journal of Field Ornithology 66:270-276.

FLINT, P.L., REED, J.A., FRANSON, J.C., HOLLMÉN, T.E., GRAND, J.B., HOWELL, M.D., LANCTOT, R.B., LACROIX, D.L., and DAU, C.P. 2003. Monitoring Beaufort Sea waterfowl and marine birds. OCS Study MMS 2003-037. Anchorage, Alaska: U.S. Geological Survey, Alaska Science Center. 125 p.

JOHNSON, S.R. 1990. Colonization and habitat use by Pacific eiders (Somateria mollissima v-nigra) on the Endicott Causeway, Beaufort Sea, Alaska 1989. Report for BP Exploration (Alaska) Inc., by LGL Limited. Available from BP Exploration (Alaska) Inc., P.O. Box 196612, Anchorage, Alaska 99519-6612. 23 p.

- 2000. Pacific eider. In: Truett, J.C., and Johnson, S.R., eds. Natural history of an Arctic oil field: Development and the biota. San Diego: Academic Press. 259-272.

JOHNSON, S.R., and HERTER, D.R. 1989. The birds of the Beaufort Sea. Anchorage, Alaska: BP Exploration (Alaska) Inc. $372 \mathrm{p}$.

JOHNSON, S.R., HERTER, D.R., and BRADSTREET, M.S.W. 1987. Habitat use and reproductive success of Pacific eiders Somateria mollissima v-nigra during a period of industrial activity. Biological Conservation 41:77-90.

KILPI, M., and LINDSTRÖM, K. 1997. Habitat-specific clutch size and cost of incubation in common eiders, Somateria mollissima. Oecologia 111:297-301.

LARSON, S. 1960. The influence of the Arctic fox Alopex lagopus on the distribution of Arctic birds. Oikos 11:276-305.

MANLY, B.F.J., McDONALD, L.L., and THOMAS, D.L. 1993. Resource selection by animals. London: Chapman and Hall.

NOEL, L.E., O'DOHERTY, G.M., and JOHNSON, S.R. 2002. Nesting status of the common eider and the glaucous gull in the central Alaskan Beaufort Sea, 2002. Report for BP Exploration (Alaska) Inc., by LGL Alaska Research Associates, Anchorage, Alaska. Available from BP Exploration (Alaska) Inc., P.O. Box 196612, Anchorage, Alaska 99519-6612. 80 p.

PEHRSSON, O. 1973. Chief prey as a factor regulating populations of eider (Somateria mollissima) and long-tailed ducks (Clangula hyemalis). Zoologisk revy 35:89-92. (In Swedish with English summary.)

SPSS. 2000. SYSTAT ${ }^{\circledR} 10$. Chicago, Illinois: SYSTAT Statistical Software.

SUYDAM, R.S., DICKSON, D.L., FADELY, J.B., and QUAKENBUSH, L.T. 2000. Population declines of king and common eiders of the Beaufort Sea. Condor 102:219-222.

USFWS (U.S. FISH AND WILDLIFE SERVICE). 1999. Population status and trends of sea ducks in Alaska. Unpubl. report. Available from U.S. Fish and Wildlife Service, Migratory Bird Management, 1011 East Tudor Road, Anchorage, Alaska 99503. $137 \mathrm{p}$. 